sciendo Порівняльна професійна педагогіка 8(4)/2018 Comparative Professional Pedagogy 8(4)/2018

DOI: $10.2478 /$ rpp-2018-0048

$\mathrm{PhD}$ in Pedagogy, Associate Professor, VALENTYNA PLIUSHCH

Volodymyr Vynnychenko Central Ukrainian State Pedagogical University, Ukraine Address: 1 Shevchenko S., Kropyvnytskyi, Kirovohrad Region, 25000, Ukraine

E-mail: valentynapl@ukr.net

\title{
DEVELOPING METACOGNITIVE STRATEGIES OF FUTURE TEACHERS IN THE FRENCH SYSTEM OF HIGHER EDUCATION
}

\begin{abstract}
The article analyzes the trends in teacher education development with the aim to improve the system of education in Ukraine. The need to improve professional training of future teachers taking into account metacognitive learning strategies is emphasized. The main way of enhancing efficiency of professional knowledge acquisition is defined to be metacognitive processes. The study of psychopedagogical literature shows variety and diversity of scientific approaches to undestanding the essence of metacognitions. It is indicated that the implementation of metacognitive approach is impossible, unless the student possesses the knowledge of learning strategies. When the lecturer aims to develop them in the students, learning becomes more personality-oriented and the level of learner autonomy is increased and thinking is amplified. This, in turn, is one of the most important ways to develop self-study skills. Foreign educational science singles out three groups of learning strategies such as cognitive, socially affective and metacognitive (being the main element of educational actions). The methods of metacognitive learning in higher education institutions in France are analyzed. The metacognitive learning pattern of note-taking is defined as to be most practice-oriented. It consists of such stages as contextualization, decontextualization and recontextualization. The analysis of training programmes for future teachers proves that the implementation of metacognitive programmes into practice of higher teacher education in France is based on the following two processes: either their full assimilation with the already existing syllabi, or the expansion of syllabi with the specialized course of study in metacognitive learning. Therefore, these programmes urge lecturers to realize that under modern conditions it is necessary to switch to metalearning. Students are assisted in creating a list of competences and knowledge and are aware of the need to enhance them in the future. The analysis of metacognitive programmes for professional training of future teachers in France concludes that lecturers aim to develop future teachers' ability to self-analyze and self-assess learning activities.

Keywords: learning strategies, metacognitions, metacognitive learning strategies, future teachers, professional training.

\section{INTRODUCTION}

Educational reforms promote revision of the education process models, which should meet modern requirements. The National Strategy for Education Development in Ukraine until 2021 describes the main trends, priorities and mechanisms for implementing the state education policy, the structure and content of the education system, which requires high-quality training of future specialists. Taking into consideration the fact that a component of self-directed study is increasing, it is imperative to ensure its effective organization in relation to professional training of future teachers. Nowadays, higher
\end{abstract}


education institutions lack sufficient capacity in this regard. The analysis of studies on the raised problem shows that some European Union countries, in particular France, have applied metacognitive approach to teaching and created the conditions, which are necessary for creative activities of learners and allow them to engage in self-improvement and selfrealization. To this end, there appears to be the need study some European trends in teacher education development with the aim to improve the education system in Ukraine.

\section{THE AIM OF THE STUDY}

The aim of the study consists in analyzing the experience of developing metacognitive strategies of future teachers in higher education institutions in France and outlining relevant recommendations to im

\section{THEORETICAL FRAMEWORK AND RESEARCH METHODS}

Theoretical framework of the current study consists of the findings by Ukrainian (Yu. Adonieva, A. Derkach, O. Henisaretskyi, Yu. Hromyko, A. Smantser, O. Zhuk) and foreign (B.-M. Barth, Ch. Bonne-Dulibine, N. Carmona-Magnaldi, D. Cohen, L. Grosjean, L. Lafortune, N. Leselbaum, B. Noël, M. Romainvilleet, L. Saint-Pierre, G. De Vecci et al.) scholars, who explored theoretical and practical principles of effective organization of students learning based on metacognitive approach.

While researching, the following methods were used: analysis, synthesis, comparison, generalization with the aim to study scientific literature and compare the scholars' views on the content of the defined concepts.

\section{RESULTS}

The study of psychopedagogical sources proves variety and diversity of scientific approaches to undestanding the essence of metacognition as a special cognitive process, which enables the individual to analyze his/her own cognitive activity (J. Flavell); a specific activity which enables the individual to evaluate and monitor his/her own learning progress (A. Brown); some mental structures that systematically control information processing and organize the individual's intellectual activity (M. Kholodna); meta-systemic cognitive processes, which enable the individual to perceive his/her subjective reality, inner world (A. Karpov) (Adonieva, 2017).

Upgrading teacher education calls for creating some new schemes aimed at developing metacognitive skills and, eventually, shaping the teacher's educational and professional style (Adonieva, 2017).

It is impossible to implement metacognitive approach, unless the individual possess some knowledge of learning strategies. The concept of "strategy" is common in many fields. It is characterized by an agreement between specific traits of the coordinator of an activity and the current conditions inherent in the activity. It combines all the actions and processes according to the aim of the activity. Therefore, strategy is one of the main factors in achieving success in any activity. O. Malykhin \& A. Halla (2016) state that learning strategies are considered to be a set of actions, steps, plans, rountines, which assist the student in obtaining, preserving, accessing and using information.

Foreign educational science defines learning strategies as subjective and intellectual actions through which the learner can enhance perception of educational material and singles out three groups of learning strategies. They are the following: 1) cognitive learning strategies - conscious ways of organizing learning such as note-taking, selection of scientific sources (e.g. dictionaries), revision, drawing of parallels, memorization of terms and key concepts; 2) socially affective learning strategies - learning through interaction, 
sciendo Порівняльна професійна педагогіка 8(4)/2018 Comparative Professional Pedagogy 8(4)/2018

information exchange (e.g. peer interaction, collaboration tasks, counselling); 3) metacognitive learning strategies assist the student in planning, organizing and controlling his/her learning as well as analyzing his/her own achievements (Cohen, 2011).

When the lecturer aims to develop learning strategies in the students, learning becomes more personality-oriented and the level of learner autonomy is increased and thinking is amplified. Therefore, it is rather imperative to teach students to design their own optimal learning strategies since it is one of the main trends in the development of learning autonomy. M. Romainville (1993) views metacognitive strategies as the main element of educational actions. The studies conducted among first-year students have shown that it takes little time to improve students' learning skills and adapt them to a new context, thereby increasing the efficiency of self-directed study (Romainville, 1993, p. 3).

According to M. Romainville (1993), the student who seeks to be able to control his/her own learning activities must understand and contextualize his/her learning style. Academic success also depends on his/her ability to analyze certain cognitive strategies and factors influencing their implementation, as well as his/her ability to adapt the strategies to personal characteristics and characteritics of learning activities (p. 4). On the one hand, learning involves using these strategies to control cognitive processes. On the other hand, learning is also a result, since the students' use of these strategies should result in modified knowledge as a cognitive structure for long-term memorization.

M. Romainville (1993) indicates that knowledge modification can be achieved:

- through different changes such as adding of new information to previously acquired knowledge and, as a result, its restructuring, elimination of some knowledge, emergence of new connections within knowledge;

- depending on a type of transformed knowledge;

- depending on a level of transformed knowledge perception (Romainville, 1993, p. 9).

B.-M. Barth (1987) believes that students who passively receive knowledge will never be able to engage in self-directed study (pp. 35-70). When designing a model for developing metacognitions, the scholar discovered that their own underdevelopment could be explained by lack of knowledge among students at the level of abstraction. Therefore, B.-M. Barth designed a metacognitive model of learning situation, which took into account the chronology of metacognitive actions and involved three stages. Stage 1 is aimed at conceptualization of an educational problem and reflection on students' results, so that they can familiarize themselves with some effective ways of performing learning tasks. First, students should put forward some hypotheses, which are subject to verification. After that, they learn how to formulate a general idea taking into account the examples produced by the lecturer. Students are also taught how to distinguish some characteristics of phenomena, compare them and eliminate insignificant ones. In such a way, they learn how to classify the examples according to certain criteria.

Stage 2 control the accuracy of problem conceptualization with new examples. In case of the collision of perceptions, the cognitive conflict is more valuable than "a ready response". Students' recognition of mistakes becomes a source of metacognitive development.

Stage 3 involves determining effectiveness of learning actions and evaluating the possibility of transferring knowledge to other fields. The final grade is calculated individually. Its main criteria should be based on the following abilities: to recognize the studied concept taking into account new examples; to justify one's choice and outline the main features of the concept; to correlate the essence of the concept with its features, which 
makes it possible to evaluate the structure of knowledge and the achieved metacognitive level of abstraction; to illustrate the concept with one's own examples; to transform these examples into other concepts (Barth, 1987). This model, however, lacks group work, which is important in developing core competencies of a modern teacher.

The metacognitive learning pattern of note-taking suggested by M. Romainville and B. Noël (1998) is defined as to be most practice-oriented. It consists of the following stages:

- contextualization. The authentic nature of learning situation (taking notes, keeping a record of the meeting, making an abstract of learning materials) requires that students should wisely choose learning strategies. Such an activity is cosidered to be metacognitive if the student can comprehend the essence of his/her actions, analyze his/her notes, compare them with those of other students, justify his/her choice of the strategy.

- decontextualization. The first element of this stage is metacognitive pause, which takes place during note-taking or directly after its completion. The student analyzes the used strategies, reflects on the result, as well as the criteria for evaluating the activity, identifies some persistent features of these strategies.

- recontextualization. This stage should facilitate the application of previously acquired skills under new learning situations. The student should be able to define whether these skills are effectively applied. The main task of this stage is to teach students how to use these skills and microcompetences when performing new learning tasks. Thus, the suggested model proves that developent and use of knowledge require that students should organize their own thinking activity (Kazimirskaya, \& Torkhova, 2002, p. 78).

French scholars state that self-directed study can be effective if the lecturer is able to establish goal-setting, plan learning activities, provide students with effective assistance and evaluate their results (Leselbaum, Bonne-Dulibine, \& Grosjean, p. 20). Therefore, students should be able to use various knowledge, predict the results of learning actions and self-assess (assess) learning activities.

L. Lafortune and L. Saint-Pierre (1998) believe that metacognitive and affective learning can be effective if students are involved into active learning. Indeed, if the lecturer allocates $8-10 \%$ of total learning time to metacognitive training, probability of success increases (pp. 35-39). The programme of metacognitive learning should contain some common activities not to disrupt the rhythm of the education process. However, the lecturer who wants to improve his/her own style should introduce pedagogical innovations.

The analysis of training programmes for future teachers proves that the implementation of metacognitive programmes into practice of higher teacher education in France is based on the following two processes: either their full assimilation with the already existing syllabi, or the expansion of syllabi with the specialized course of study in metacognitive learning.

De Vecci designed a special course for students to help them organize their selfdirected study at interdisciplinary level, which is based on the author's pattern of knowledge creation. It consists of four modules, namely research module (familiarization with an educational problem), concept module (acquisition of experience in structuring knowledge), knowledge generalization and verification module, knowledge application (De Vecci, \& Carmona-Magnaldi, 1996, p. 202).

J.-L. Wolfs designed a programme for future teachers based on metacognitive approach. The programme aims to teach students metacognitive reflection, metacognitive strategies and time managament, which is necessary for effective organization and implementation of self-directed study. The author took into account cognitive, affective and 
sciendo Порівняльна професійна педагогіка 8(4)/2018 Comparative Professional Pedagogy 8(4)/2018

metacognitive factors, the latter being able to prevent narrow specialization of professional teacher training. In accordance with the pattern for metacognitive teaching of note-taking, J.-L. Wolfs designed the following plan of self-directed study:

1) the lecturer offers students to make an abstract of the lecture;

2) the lecturer analyzes students' results and encourages them to explain how they organized their learning activities. This makes it possible to specify whether students applied the same or different methods while performing learning tasks. Students are also offered to independently design the criteria for evaluation and self-evaluation of results;

3) the lecturer assists students in mastering the note-taking method;

4) the lecturer offers students some exercises and means, which can help them to improve some skills. Each student is involved into metacognitive pause to comprehend his/her own achievements and overcome difficulties;

5) the lecturer can choose the mode of programme application (individual or group counselling; individual classes or the whole course; individual work, pair work, group work, etc.) (Romainville, 1998).

Therefore, these programmes urge lecturers to realize that under modern conditions it is necessary to switch to metalearning. Students are assisted in creating a list of competences and knowledge and are aware of the need to enhance them in the future. The analysis of metacognitive programmes for professional training of future teachers in France concludes that lecturers aim to develop future teachers' ability to self-analyze and self-assess learning activities.

\section{CONCLUSIONS}

Therefore, the application of metacognitive strategies for learning organization and self-directed study of students creates some optimal conditions for them to demonstrate their skills and to become active participants in the education process. The conducted analysis of metacognitive component in teacher training programmes in France proves that its system of higher teacher education is characterized by theoretically and methodically justified educational practice aimed at developing metacognitions of students (the ability to plan, organize and control their own activities based on metacognitive strategies).

The experience of using metacognitive strategies in training future teachers in higher education systems of some European Union countries can be taken into account in by Ukrainian educators. The already existing developments insufficiently cover the specificity of professional training of natural sciences teachers and should be more widely researched.

\section{REFERENCES}

1. Adonieva, Yu. A. (2017). Metakohnityvne navchannia maibutnikh fakhivtsiv u vyshchykh navchalnykh zakladakh: dosvid ta osoblyvosti vprovadzhennia. ScienceRise. Pedagogical Education, 6, 10-13.

2. Kazimirskaya, Y. Y., \& Torkhova, A. V. (2002). Obshchie osnovy pedagogycheskoi professii. Molodechno: Pobeda.

3. Malykhin, O. V., \& Halla, A. O. (2016). Sutnist fenomenu "stratehii navchannia" u fakhovii pidhotovtsi studentiv filolohichnykh spetsialnostei. Visnyk Chernihivskoho natsionalnoho pedahohichnoho universytetu. Seriia: Pedahohichni nauky, 133, 120-123.

4. Barth, B.-M. (1987). L'apprentissage de l'abstraction. Paris: Retz.

5. De Vecci, G., \& Carmona-Magnaldi, N. (1996). Faire construire des saviors. Paris: Hachette Éducation. 
sciendo Порівняльна професійна педагогіка 8(4)/2018 Comparative Professional Pedagogy 8(4)/2018

6. Lafortune, L., \& Saint-Pierre, L. (1998). Affectivite et métacognition dans la class. Bruxelles: De Boeck.

7. Leselbaum, N., Bonne-Dulibine, Ch., \& Grosjean, L. (1993). Travail Autonome et Travail Personnel de l'élève. Paris: ERREUR PERIMES Institut national de recherche pédagogique.

8. Romainville, M. (1993). Savoir parler de ses méthods. Métacognition et performance à l'université. Bruxelles: De Boeck Université.

9. Romainville, M., \& Noël, B. (1998). Les dispositifs d'accompagnement pedagogique au premier cycle. Gestion de l'enseigment supérieur, 10 (2), 63-80.

10. Cohen, A. D. (2011). Strategies in learning and using a second language. Harlow: Pearson Education Ltd. 